\title{
British scientists wait for crucial decision that could ease pressure on promotions
}

In two weeks the Science Research Council is to make a decision on a controversial plan aimed at easing the critical staff stagnation problem which now affects universities in the UK. On 18 July, its central council will decide whether or not to give the go-ahead to a special release fellowship scheme that is intended to help more senior research workers vacate tenured posts which can then be filled by young scientists.

The age structure at UK universities has been deteriorating since the higher education expansion of the early 1960s, when new departments were created and were manned at senior levels with young scientists. In recent years, economic recession has ended the creation of additional posts and the distribution of posts has been frozen.

Indeed, in some science departments there have been no new appointments for the past ten years. Where there have been vacancies these have been filled from within departments, thus halting the crucial flow of ideas and talent between universities.
Now, in an attempt to stop this stifling of fresh talent, the SRC is seriously considering the establishment of special fellowships which would fund research workers advanced in their careers and allow them to leave university posts to concentrate solely on research without administrative responsibilities. Their vacated positions would then be filled by young scientists and over subsequent years allow the phasing-in of new research workers.

However it is stressed that the scheme is not meant as a form of premature retirement for ageing researchers, and only those who are active and still have important scientific contributions to make will be considered for funding.

The proposal to be discussed by the SRC this month is for 15 fellowships to be set up in the first year of the programme with further annual increments of 10 new awards. This could then provide a total of 45 special release fellowships within four years.

But there are several difficulties associated with this plan. For one thing, it has not yet been agreed whether the SRC should pay for the senior researcher's salary or if it should pay for the junior post. The difference could represent a variation of about $50 \%$ in final costs and consequently estimates vary between $£ 300,000$ and $£ 450,000$ a year for the ultimate price of the full fellowship scheme.

However the council is at present particularly concerned about its future budget allocations and may be very reluctant to commit itself to such a level of funding. At its meeting, it may decide to cut the numbers of fellowships or may even postpone any decision until September when it hopes to learn its financial guidelines for the coming years.

Indeed, some council members are very cautious about the whole idea of the scheme, believing it be the role of the University Grants Committee to provide proper staff structures within departments. Combined with these other factors, this view puts the council's coming decision very much in the balance.

Robin McKie

\section{Dearer oil puts brake on Third World growth}

THE effect of the current energy crisis on Western nations has attracted considerable international attention but precious little has been said about the non-OPEC Third World countries. Energy experts who gathered at a forum on 'Third World Energy Strategies and the Role of Industrialised Nations' organised recently (20-22 June) by the Royal Institution in London, described an extremely critical energy situation developing shortly in these countries, which could almost threaten their very survival.

Their predicament was well illustrated by a case study of Kenya presented by T.S. Tuschak, a UN energy consultant based in Nairobi. Mr Tuschak pointed out that Kenya consumed in 1978 a little less than 12 million barrels of oil (equivalent to about one week's consumption in Canada). This small quantity of oil accounted for about $85 \%$ of the energy consumed by the country's modern sector. About $80-82 \%$ of this oil was consumed in essential sectors like industry, agriculture and goods transport. The rest was accounted for by private automobiles, which too in many cases were not inessential because of an underdeveloped public transport.

The possibility of oil savings in the essential sectors is at best $7 \%$. Consumption by private transport can at best be reduced by about $10 \%$. Kenya, therefore, has few options but to maintain oil imports at near current levels, and will possibly even have to increase them if the economy continues to grow.
Tuschak estimates that for $\$ 1 /$ barrel increase in oil price, the country's export earnings would have to increase by about $1 \%$ over the 1978 level. This expansion in exports may sound small but could well be impossible considering the global slow down in economic growth.

Coffee and tea represent $50-60 \%$ of Kenya's total exports and they are about the only commodities in the country capable of any significant expansion in world markets. Their export would have to increase by as much as $30 \%$ in a year to cover the incremental foreign exchange needs. "The only way to meet this bill," said Tuschak, quite despondently, "is to further impoverish the country, by paying for oil by funds destined for development". Few developing countries will be able to afford an oil price of $\$ 20-22 /$ barrel.

The other possibility, of course, is for Western countries to bale out the developing countries. But this option brought forth only a spirited discussion, virtually no agreement.

Stephen Bosworth, the US Ambassador to Tunisia, and former chairman of NorthSouth negotiations on energy at Paris, plainly warned Third World energy planners that Western aid and loans from international financing institutions are unlikely to rise fast enough to meet the needs generated by oil price rises. Nor is an oil sharing system which gives preferences to developing countries is likely to come into operation he said. The world will have a slower rate of growth in the future. "We have seen that Western parliaments react unfavourably to any real transfer of resources in those conditions."

The discussions on alternate energy sources that could replace oil revealed two important Third World concerns: first, that the Third World is extremely unhappy with the constant preaching by Western scientists and technologists that unconventional energy sources like wind and solar power, and fuelwood plantations are best for it. All Third World energy experts gathered in London agreed that these energy sources would be good for developing countries but they would first want them to be fully tried and tested.

Secondly, they pointed out, none of these sources can provide an alternative to oil in the short-term which is really the critical period for the non-oil producing Third World.

Dr A. K. N. Reddy of the Indian Institute of Science at Bangalore threw an outright challenge to the developed countries: "Teach us to live without oil but by doing it yourselves". That the developed countries must first put their own house in order was a demand that was echoed by many Third World participants.

Dr Joao A. Meyer, of the State University of Campinas in Sao Paulo, criticised Western efforts for following their traditional approach to technology transfer even in the new field of nontraditional energies. They are once again trying to sell gadgets, instead of trying to 